\title{
BENTUK MEDIA EDUKASI PERILAKU SEKSUAL BERISIKO UNTUK REMAJA TINGKAT SEKOLAH MENRENGAH PERTAMA DI KABUPATEN BADUNG PROPINSI BALI
}

\author{
Moh. Fairuz Abadi
}

\begin{abstract}
Health promotion is a process to build self awareness to avoid of the health risk. Education about sexual risk behavior for teenagers is one of them. Education media had a function to communicate and spread the information of health. The education media on sexual risk behavior for teenagers was a important thing for health promotion programe. The research pupouse are to expose and describes the form of education media on sexual risk behavior for teenagers at junior high schools in Badung Regions by using qualitaive method. The respondens are choice by purposive. The result shown that there is many form of education media for sexual risk behavior for teenagers, wich are booklet, power poin slide, leaflet/brocure, social media, video, TV,book and peer. Media that was ever used are booklet, power poin slide, leaflet/brocure, social media and article. Media that was more used are social media, leaflet/brocure and power poin. There is no information about the effectivity level of media. The outcame of education media for sexual risk behavior only increase cognitive aspect. Based from all of respondens speaks, media which is suitable are slide/power poin, leaflet/brocure, sosial media dan video.
\end{abstract}

Key words : health promotion, media, teenagers.

\begin{abstract}
ABSTRAK
Promosi kesehatan adalah proses penyadaran untuk menumbuhkan kesadaran dalam diri untuk menghindari faktor resiko tertentu . Edukasi terhadap perilaku seksual berisiko pada remaja adalah salah satunya Media sebagai alat peraga dalam promosi kesehatan berfungsi sebagai alat bantu untuk komunikasi dan menyebarluaskan informasi, berbagai bentuk media edukasi tentang perilaku
\end{abstract}


seksual berisiko turut menentukan efektivitas promosi kesehatan. Penelitian ini bertujuan untuk mengekspose dan mendeskripsikan tentang bentuk media edukasi perilaku seksual berisiko untuk remaja tingkat sekolah menengah pertama di Kabupaten Badung menggunakan pendekatan kualitatif. Responden penelitian dipilih secara purposive.

Hasil penelitian, bentuk media yang diketahui adalah lembar balik, slide power poin, leaflet/brosur, media sosial, tayangan video, tv, buku-buku, dan teman sebaya. Media yang pernah digunakan adalah lembar balik, media sosial, leaflet/brosur, slide/Power Poin dan artikel di majalah. Media yang paling sering digunakan adalah media sosial disusul oleh leaflet dan slide power poin. Tingkat keberhasilan dari hasil media yang paling sering digunakan belum dapat diketahui. Dampak media edukasi terhadap perilaku remaja adalah menambah aspek kognitif. Media yang cocok untuk edukasi adalah slide/power poin, leaflet/brosur, media sosial dan video.

\section{Kata kunci : Promosi kesehatan, media, remaja}

\section{Pendahuluan}

Edukasi terhadap perilaku seksual berisiko pada remaja adalah salah satu upaya dalam mencegah dan menanggulangi aktivitas seksual dini, transmisi infeksi menular seksual, kehamilan tidak diinginkan, dan moral serta nilai remaja sebagai insan pelajar. Menurut UU No 4 tahun 1979 mengenai kesejahteraan anak disebutkan bahwa remaja adalah individu yang belum mencapai usia 21 tahun dan belum menikah, Sebagai insan pelajar, remaja di Indonesia memiliki kewajiban dan hak yang sama untuk belajar, khususnya di lingkungan formal, yaitu sekolah. Sesuai dengan Peraturan Pemerintah Republik Indonesia Nomor 47 Tahun 2008 tentang wajib belajar, pada pasal 12 dijelaskan bahwa setiap warga negara Indonesia usia wajib belajar wajib mengikuti program wajib belajar. Menurut PERMENDIKBUD RI Nomor 19 tahun 2016 tentang Program Indonesia Pintar dijelaskan bahwa melalui program Indonesia Pintar, pemerintah mendukung pelaksanaan pendidikan menengah universal atau rintisan wajib belajar 12 (dua belas) tahun dimulai pada usia 6 sampai 21 tahun. 
Promosi kesehatan pada remaja adalah proses penyadaran yang berkaitan dengan bagaimana menumbuhkan kesadaran dalam diri remaja untuk menghindari faktor resiko tertentu yang menjadi penyebab penyebaran penyakit. Promosi kesehatan perilaku seksual remaja berbasis sekolah tumbuh dan berkembang dalam rangka untuk mencegah, mengurangi insiden, mendukung pengobatan dan menciptakan upaya yang kondusif. Basis dari promosi kesehatan tersebut adalah terjadinya transfer informasi, transfer pengetahuan dari dewasa kepada remaja menggunakan media edukasi efektif, selanjutnya informasi dan pengetahuan tersebut ditteruskan melalui remaja kepada remaja yang lain (peer), sehingga diharapkan akan terbentuk persepsi yang sama sebagai tindakan antisipatif terhadap perilaku seksual berisiko yang membahayakan kesehatan fisik dan psikologis remaja. Meskipun demikian remaja masih rentan terhadap pengaruh perilaku seksual berisiko.

Perlindungan remaja terhadap perilaku seksual pada remaja, salah satunya diatur oleh undang-undang yang disahkan pemerintah melalui Peraturan Presiden nomor 7 tahun 2005, yang menyebutkan hak untuk menjadi diri sendiri dalam artian bebas mengekspresikan diri, membuat keputusan, menjadi aman; hak untuk tahu tentang kesehatan reproduksinya atau HIV/AIDS; hak untuk dilindungi dan melindungi diri dari pelecehan seksual, aborsi, Kehamilan Tidak Diinginkan (KTD), Infeksi menular Seksual (IMS); hak untuk mendapat pelayanan kesehatan yang bersahabat, tanpa mendiskriminasi, secara profesional oleh ahlinya; dan hak untuk terlibat dalam segala hal dalam kebijakan pemerintah tentang remaja (Muhajir dkk, 2007).

Penelitian ini bermaksud mendeskripsikan bentuk media edukasi di sekolah terhadap remaja berkaitan dengan perilaku seksual berisiko, khususnya di wilayah kabupaten Badung Propinsi Bali. Topik yang akan diperdalam (indepth) meliputi media apa saja yang diketahui dipakai dalam menyampaikan materi tentang perilaku seksual berisiko pada remaja, media apa sajakah yang pernah digunakan, media apa saja yang sering dipakai, bagaimana hasil dan dampaknya terhadap perilaku remaja dan media pa yang menurut responden cocok dipakai pada edukasi perilaku seksual berisiko pada remaja di sekolah.

\section{Rumusan Masalah}


1. Media apa saja diketahui untuk meyampaikan materi tentang perilaku seksual berisiko pada remaja SMP?

2. Media apa sajakah yang pernah digunakan dalam program edukasi tentang perilaku seksual berisiko pada remaja di sekolah menengah pertama (SMP)?

3. Media apa yang paling sering sering digunakan dalam program edukasi tentang perilaku seksual berisiko pada remaja di sekolah menengah pertama (SMP)?

4. Bagaimana hasil dari media yang sering digunakan tersebut?

5. Bagaimana dampaknya media edukasi secara luas terhadap perilaku remaja di Kabupaten Badung?

6. Media seperti apa yang cocok digunakan untuk edukasi tentang perilaku seksual berisiko pada remaja di sekolah menengah pertama (SMP), sesuai dengan kondisi dan situasi di Kabupaten Badung?

\section{Tujuan Penelitian}

Tujuan umum penelitian ini adalah untuk mengekspose dan mendeskripsikan tentang bentuk Media Edukasi Perilaku Seksual Berisiko untuk remaja tingkat sekolah menrengah pertama di Kabupaten Badung Propinsi Bali. Tujuan khusus adalah untuk mengetahui :

1. Media yang diketahui untuk meyampaikan materi tentang perilaku seksual berisiko pada remaja SMP.

2. Media yang pernah digunakan dalam program edukasi tentang perilaku seksual berisiko pada remaja di sekolah menengah pertama (SMP)?

3. Media yang paling sering digunakan dalam program edukasi tentang perilaku seksual berisiko pada remaja di sekolah menengah pertama (SMP)

4. Hasil dari media yang sering digunakan tersebut

5. Dampak media edukasi secara luas terhadap perilaku remaja di kabupaten Badung

6. Media yang cocok digunakan untuk edukasi tentang perilaku seksual berisiko pada remaja di sekolah menengah pertama (SMP), sesuai dengan kondisi dan situasi di kabupaten Badung.

\section{Metode}


Penelitian ini dilaksanakan dengan pendekatan metode kualitatif, data yang dihasilkan berupa kata-kata tertulis maupun lisan (script) yang teramati oleh peneliti. Fokus penelitian ini adalah pada bentuk media edukasi di sekolah terhadap remaja, yaitu meliputi media apa saja yang diketahui dipakai, media apa sajakah yang pernah digunakan, media apa saja yang sering dipakai, bagaimana hasil dan dampaknya terhadap perilaku remaja dan media apa yang menurut responden cocok dipakai pada edukasi perilaku seksual berisiko pada remaja di sekolah menengah pertama.

\section{Hasil Penelitian}

\section{Gambaran Lokasi Penelitian}

Kabupaten Badung adalah satu dari delapan kabupaten dan satu kota di Bali. Secara geografis terletak pada posisi 08 ${ }^{\circ} 14^{\prime} 17^{\prime \prime}$ - 08 $50^{\circ} 57^{\prime \prime}$ Lintang Selatan dan $115^{\circ} 05^{\prime} 02^{\prime \prime}$ - $115^{\circ} 15^{\prime} 09^{\prime \prime}$ Bujur Timur, membentang di tengah-tengah Pulau Bali. Luas Kabupaten Badung adalah 418,52 km2 atau 7,43\% luas Pulau Bali. Bagian utara daerah ini berbatasan dengan kabupaten Buleleng, di bagian selatan merupakan berbatasan langsung dengan Samudra Indonesia. Bagian timur berbatasan dengan Kabupaten Gianyar dan kota Denpasar di sebelah Barat berbatasan dengan kabupaten Tabanan (Profil Kabupaten Badung dalam http://www.badungkab.go.id/index.php/profil/1/Profil).

Jumlah total SMP di Badung pada tahun 2015 adalah 53 sekolah yang terdiri atas 21 sekolah negeri dan 32 sekolah swasta (http://badung.siaponline.com). Kegiatan edukasi pada remaja dilaksanakan secara kontinyu dengan melibatkan berbagai institusi pemenrintah dan swasta, diantaranya adalah KPAD (Komisi penggulangan AIDS Daerah), BNN, Dinas Pendidikan, Dinas Kesehatan, BKKBN, Kantor Perlindungan Anak dan Pemberdayaan Perempuan, NGO Kisara, NGO SPeKTRA, NGO YAKEBA. Bentuk kegiatan edukasi meliputi penyuluhan, kompetisi duta, peringatan hari AIDS, Jambore KSPAN, GenRe. Tujuan kegiatan tersebut adalah sebagai upaya pencegahan terhadap perilaku seksual berisiko diantaranya infeksi menular seksual (IMS), Kehamilan tidak diinginkan (KTD), hubungan seksual berisiko tinggi dan hubungan seksual pra nikah. Sumber dana kegiatan edukasi berasal dari pemerintah daerah kabupaten 
Badung, serta kegiatan Corporate Social Responsibility (CSR) (KPAD Badung, 2012).

\section{Profil Responden}

Responden dalam penelitian ini dipilih secara purposive dengan kriteria responden sebagai berikut :

1. Pengampu program edukasi perilaku seksual berisiko

2. Pengalaman pengampu program minimal lima tahun

3. Siswa yang saat ini tengah duduk di bangku skolah tingkat SMP/SLTP di Kabupaten Badung

4. Responden bersedia memberikan keterangan yang jujur tanpa tekanan dari pihak manapun.

5. Responden menyatakan kesediaanya bahwa pernyataan hasil wawancara akan direkam sebagai data penelitian.

Tabel Koding, Inisial responden dan Asal Responden

\begin{tabular}{|r|r|r|}
\hline Kode & Inisial Responden & Asal Responden \\
\hline R1 & AR & KPAD Kabupaten Badung \\
\hline R2 & PW & KPAD Kabupaten Badung \\
\hline R3 & AC & KPAD Kabupaten Badung \\
\hline R4 & NB & Siswa SMP \\
\hline R5 & AM & Siswa SMP \\
\hline R6 & DW & Siswa SMP \\
\hline R7 & DA & Siswa SMP \\
\hline
\end{tabular}

AR dengan kode responden R1 adalah seorang perempuan berusia 21 tahun, latar belakang pendidikan adalah diploma III bidang kesehatan, pengalaman di bidang edukasi remaja di Kabupaten Badung adalah sebagai pelaksana program pada sebuah NGO, kemudian dilanjutkan sebagai pengelola program di KPAD Kabupaten Badung.

PW dengan kode responden R2 adalah seorang perempuan berusia 30 tahun. Latar velakang pendidikan adalah sarjana bidang kesehatan, latar belakang asal responden adalah staf pengelola program di KPAD Kabupaten Badung. 
AC dengan kode responden $\mathrm{R} 3$, adalah seorang perempuan berusia 39 tahun, latar belakang pendidikan adalah sarjana sosial, AC memiliki pengalaman sebagai pengelola program Global Fund. Global fund adalah organisasi internasional yang dibentuk oleh PBB mempuntai tujuan untuk meningkatkan sumber daya dalam rangka mencegah, mengobati merawat dan memberi dukungan kepada orang-orang yang hidup dengan HIV AIDS (OHDA), AC terlibat dalam kegiatan bersama Global Fund sejak tahun 2007-2010, saat ini AC menjabat sebagai koordinator kegiatan di KPAD Kabupaten Badung.

NB dengan kode responden R4 adalah seorang remaja laki-laki berusia 15 tahun, NB adalah siswa kelas 9 SMP di kabupaten Badung, NB aktif dalam kegiatan PIK R. PIK R (Pusat Informasi dan Konseling Remaja) adalah suatu wadah kegiatan PKBR (Perencanaan Kehidupan Berkeluarga Bagi Remaja) yang dikelola dari, oleh dan untuk remaja guna memberikan layanan informasi dan konseling tentang perencanaan kehidupan berkeluarga bagi remaja, bentuk kegiatan yang dilaksanakan antara lain adalah ketrampiilan hidup, layanan konseling permasalahan remaja, edukasi pendewasaan usia nikah dan kegiatan edukasi lain yang berkaitan.

AM dengan kode responden R5 adalah perempuan berusia 15 tahun, AM adalah salah satu siswa sebuah SMP di Kabupaten Badung kelas 9. DW dengan kode responden R6 adalah perempuan berusia 14 tahun, DW adalah salah satu siswa sebuah SMP di Kabupaten Badung kelas 8. DA dengan kode responden R6 adalah perempuan berusia 14 tahun, AM adalah salah satu siswa sebuah SMP di Kabupaten Badung.

\section{Media penyampaian materi tentang perilaku seksual berisiko pada remaja SMP.}

Pertanyaan penelitian berikut ini bermaksud untuk mengungkap pernyataan masyarakat tentang jenis media apa saja yang diketahui oleh masyarakat sebagai sarana untuk menyampaikan materi perilaku seksual berisiko pada remaja di Kabupaten Badung. Hasil wawancara menunjukkan berbagai macam media edukasi adalah lembar balik, slide power poin, leaflet/brosur, media sosial, tayangan video, tv, buku-buku, dan teman sebaya. 
Media edukasi lembar balik diketahui oleh R1, R3 dan R4. R1 menyatakan bahwa "kalau menurut saya media itu banyak ya, ada lembar balik. .." R3 menyatakan bahwa "mungkin ada satu lagi ya yang disiapkan kayak lembar balik mungkin ya, lembar balik dengan ilustrasi yang mudah dipahami anak sesusia itu." R4 menyatakan "kadang-kadang saya juga saya membacanya dari lembar balik pada saat saya latihan PIK R”. Berdasarkan fakta hasil penelitian tersebut dapat disimpulkan bahwa media edukasi telah lembar balik diketahui sebagai sarana penyampaian materi perilaku seksual berisiko pada remaja oleh masing-masing latar belakang asal responden yaitu dari 1 responden dari kalangan siswa dan 2 responden dari kalangan KPAD Kabupaten Badung.

Media edukasi selanjutnya yang diketahui oleh responden adalah slide power poin, tipe media ini diketahui oleh empat responden yaitu R1, R3, R6 dan R7. R1 menyebutkan “................ada juga power point.........”. R3 menyebutkan pendapatnya tentang penggunaan slide power poin dalam pernyataan berikut "kalau sementara ini sih mungkin masih pakai slide ya, jadi masih berupa penyuluhan sosialisasi yang saya lihat." R6 menyebutkan "biasanya pada umumnya itu biasanya dipakai untuk menyampaikan materi tentang perilaku seksual itu biasanya seperti media cetak, seperti buku, atau koran lalu media social dan media power point" dan R7 menyebutkan “......................juga power point seperti penyuluhan-penyuluhan”. Berdasarkan fakta hasil wawancara diketahui bahwa media slide power poin diketahui oleh 2 responden dari kalangan KPAD badung dan 2 responden dari kalangan siswa SMP.

Media selanjutnya adalah leaflet/brosure penggunaan media leaflet dalam penyampaian materi perilaku seksual berisiko disebutkan oleh R1,R2 R3 dan R5. R 1 meyebutkan kalau menurut saya media itu banyak ya,

ada Liflet, ada brosur, kemudian ada juga.................".. R2 menyebutkan dalam hasil wawancara berikut juga adanya .........liflet tentang informasi tentang perilaku beresiko ini”. ". R3 dan R5 menyebutkan brosur pada beberapa potongan kalimat yang mengindikasikan pengetahuannya tentang mendia tersebut sebagai sarana penyampaian materi perilaku seksual berisiko pada rremaja. Berdasarkan fakta hasil wawancara, diketahui bahwa media leaflet/brosur diketahui lebih 
banyak oleh responden yang berasal darri kalangan KPAD Badung yaitu 3 responden dan hanya 1 dari kalangan siswa SMP.

Media sosial sebagai sarana penyampainan materi perilaku seksual berisiko untuk remaja disebutkan oleh R1, R2, R5, R6 dan R7. Media sosial diketahui lebih banyak oleh kalangan siswa SMP yaitu 3 responden, sedangkan darri kalangan KPAD Badung 2 responden. R1 menyatakan "media yang lain mungkin dari jenis social media ya, itu misalnya seperti instagram, facebook kayak gitu". R2 menyatakan "Kemudian yang lagi hits sekarang adalah media social seperti misalnya facebook, twitter, instagram, semuanya itu sangat membantu dalam kita memberikan informasi kepada remaja karena kita saat ini media social yang sedang digandrungi oleh remaja jadi adalah celah kita masuk ke komunitasnya mereka. Mereka lagi senang-senangnya facebookan jadi kita langsung memberikan informasi disana itu mereka akan baca disana" . R5dan R6 dalam pernyataannya menyebutkan tentang media sosial, sedangkan R7 menyebutkan "setahu saya, yang banyak menyampaikan materi tentang perilaku seksual beresiko itu media social seperti instagram".

Tayangan Video sebagai sarana sarana penyampainan materi perilaku seksual berisiko diungkapkan oleh R1, R2, dan R3 ketiganya berasal dari kalangan KPAD Badung, tidak satupun siswa SMP menyebutkan tentang video sebaggai sarana. R1 "nah menurut saya video itu yang lebih tepat untuk menjelaskan karena dari video itu selain ada gambar juga ada suara yang akan menjelaskan....". R2 menyebutkan "informasi tentang perilaku beresiko ini kemudian ada media elektronik berupa video...." R3 dalam pernyataannya menyampaikan "ada pemutaran video mungkin ya.............".

Buku juga diketahui oleh beberapa responden sebagai media penyampaian materi perilaku seksual berisiko pada remaja, R3 menyatakan “ kalau saya disini kalau dari buku itu media juga mungkin ya". R5 menyatakan "biasanya pada umumnya itu biasanya dipakai untuk menyampaikan materi tentang perilaku seksual itu biasanya seperti media cetak, seperti buku....", dan R6 menyebutka dalam pernyataannya "setahu saya, yang banyak menyampaikan materi tentang perilaku seksual beresiko itu media social seperti instagram dan media cetak seperti buku-buku..." 
Media TV, disebutkan oleh responden dari kalangan KPAD badung sebagai media yang diketahui sebagai media penyampaian materi perilaku seksual berisikooleh R4 yang berasal dari kalangan siswa SMP disebutkan oleh R4 dalam petikan wawancara " biasanya saya melihat dari TV....."

Media teman sebaya dan media pementasan drama hanya ditemukan pada petikan wawancara R1 dan R3. R3 menyebutkan "kemudian ada juga pementasan drama gitu ya tentang efek kalau kita menceritakan efek jera. kalau itu dibikinkan drama yang diperankan atau tema ceritanya itu tentang kenakalan remaja gitu ya sehingga mereke melihat langsung gimana sih perilaku-perilaku itu kalu misalnya kita melakukan hal seperti itu". R1 menyebutkan bahwa "kemudian ada juga media teman sebayanya yang bisa dipakai untuk menyampaikan informasi itu"

Media yang pernah digunakan dalam program edukasi tentang perilaku seksual berisiko pada remaja di sekolah menengah pertama (SMP) di kabupaten Badung.

Pada bagian ini peneliti bermaksud untuk menggali informasi lebih lanjut berdasarkan dengan jenis-jenis media yang telah diketahui oleh responden, menurut pengalaman mereka sebagai pengelola program di KPAD Badung dan sebagai siswa (subjek program), jenis-jenis media apa saja yang pernah digunakan dalam program edukasi tentang perilaku seksual berisiko pada remaja di sekolah menengah pertama (SMP) di kabupaten Badung.

Berdasarkan karakteristik responden dari kalangan siswa dapat diketahui bahwa pengalaman mereka sebagai subjek program berada pada rentang waktu 13 tahun program yang pernah diterima oleh responden (R4, R5, R6). Berdasarkan karakteristik responden dari kalangan $\operatorname{KPAD}$ Badung (R1, R2, R3) dapat dijelaskan bahwa latar belakang (background) lama masa pengalaman kerja di bidang remaja dan penganggulangan HIV/AIDS, termasuk di dalamnya adalah perilaku seksual berisiko pada remaja,dapat dijelaskan bahwa rentang waktu informasi yang terungkap berapa pada rentang waktu lebih dari 5 tahun.

Beberapa jenis media yang terungkap dalam petikan wawancara pernah digunakan yaitu media lembar balik, sosial media, liflet (leaflet/brosur), slide/Power Poin dan artikel di majalah. Lembar balik adalah media yang terbuat dari bahan kertas karton tebal, tergabung menjadi satu kesatuan, biasanya 
dijilid spiral (rol) yang berisi tentang gambar dan tulisan tentang materi tertentu dan digunakan sebagai media/sarana edukasi di kelas. Media lembar balik terkonfirmasi pernah digunakan sebagai media penyampaian materi perilaku seksual berisiko pada remaja oleh R1 dan R4. R1 menyebutkan "yang bisa digunakan untuk SMP itu yang lembar balik...” sedangkan R4 menyatakan "yang pernah digunakan itu lembar balik"

Sosial media pernah digunakan sebagai media penyampaian perilaku seksual berisiko pada remaja, hal ini terkonfirmasi dalam wawancara oleh pernyataan R1, R2 dan R7. R1 menyatakan bahwa "yang bisa digunakan untuk SMP itu yang lembar balik bisa digunakan kemudian yang liflet juga bisa digunakan, kemudian social media". R2 menyatakan"..... dan juga di facebook juga sudah sering dilihat seperti itu." Selanjutnya R7 menyatakan "media-media social yang ada informasinya tentang edukasi perilaku seksual juga......".

Leaflet atau dalam bahasa indonesia disebut brosur adalah 1 bahan informasi tertulis mengenai suatu masalah yang disusun secara bersistem; 2 cetakan yang hanya terdiri atas beberapa halaman dan dilipat tanpa dijilid; (KBBI, 2017). Effendy (1989) memberikan pengertian leaflet adalah lembaran kertas berukuran kecil mengandung pesan tercetak untuk disebarkan kepada umum sebagai informasi mengenai suatu hal atau peristiwa. Hal ini terkonfirmasi pernah digunakan sebagai media penyampaian materi perilaku seksual berisiko oleh R1 "yang bisa digunakan untuk SMP itu yang lembar balik bisa digunakan kemudian yang liflet juga bisa digunakan......". R2 menyatakan "R2 "media yang sudah, ya seperti brosur, murid itu ya sudah sering sekali ya brosur, liflet, kemudian di artikel-artikel di majalah itu sendiri itu juga sudah sering dan juga di facebook juga sudah sering dilihat seperti itu.".

Slide power poin adalah tampilan yang ditayangkan menggunakan perangkat keras dan perangkat lunak komputer, yang terhubung dengan instrumen LCD. Slide power poin terkonfirmasi dengan jelas dalam hasil wawancara yang diungkapkan oleh, R3, R6 dan R7. Bukti dari hal tersebut adalah, R3 menyatakan "seperti tadi yang saya bilang masih pakai kayak slide, LCD gitu”. R6 "media yang pernah digunakan itu pada umumnya itu power point karena agar cepat bisa menjelaskan dan tidak terlalu berbelit-belit." R7 menyatakan "media-media social 
yang ada informasinya tentang edukasi perilaku seksual juga power point seperti penyuluhan-penyuluhan".

Artikel di majalah terkonfirmasi oleh hanya satu responden yaitu R2 dalam petikan hasil wawancara R2 menyatakan "media yang sudah, ya seperti brosur, murid itu ya sudah sering sekali ya brosur, liflet, kemudian di artikelartikel di majalah..."

Media yang paling sering digunakan dalam program edukasi tentang perilaku seksual berisiko pada remaja di sekolah menengah pertama (SMP)

Pernyataan responden tentang media yang paling sering digunakan dalam program edukasi tentang perilaku seksual berisiko pada remaja di sekolah menengah pertama (SMP) sangat bervariasi, hal ini kemungkinan dipengaruhi oleh sudut pandang dan kebiasaan masing-masing responden dalam mendapatkan informasi tentang hal tersebut. Media sosial menjadi media yang paling banyak terkonfirmasi yaitu oleh R2, R6 dan R7. R2 menyatakan “ kayaknya yang sekarang ini kayaknya media social”, R6 menyatakan “yang sering digunakan itu media social karena media social itu mencakup semuanya dan semua orang bisa mengetahui apa itu perilaku seksual yang beresiko pada remaja SMP", kemudia R7 menyatakan "karena remaja itu sering menggunakan media social untuk pembelajaran". Power poin sebagai media penyampaian terkonfirmasi pada R1 dan R3, dalam pernyataannya R1 menyatakan "yang paling sering digunakan itu adalah liflet ya, karena liflet itu biasa disebar pada saat penyuluhan jadi liflet dan power poin itu sering digunakan menurut saya, dan R3 menjelaskan "yang biasa digunakan itu LCD, melalui power point itu aja". Lembar balik dan leaflet terkonfirmasi pada satu responden saja yaitu leaflet oleh R1 dan lembar balik oleh R4, R4 menyatakan "pada kegiatan sosialisasi ke kelas-kelas mengunakan lembar balik"

\section{Hasil dari media yang sering digunakan}

Berdasarkan hasil wawancara dengan seluruh responden, diketahui bahwa belum satupun responden yang dapat menjelaskan tingkat keberhasilan dari hasil media yang paling sering digunakan dalam program edukasi tentang perilaku seksual berisiko pada remaja di sekolah menengah pertama (SMP). 


\section{Dampak media edukasi secara luas terhadap perilaku remaja di kabupaten Badung}

Dampak media edukasi terhadap perilaku remaja berdasarkan informasi dari responden berkaitan dengan dampak kognitif siswa (pengetahuan atau tahu) tentang perilaku seksual berisiko. Hal ini terungkap dari hasil wawancara pada seluruh responden. R1 menyatakan sebagai berikut "kalau menurut saya dampaknya lumayan ya mengetahui pengetahuan dari siswa tersebut sehinga kan dari mereka tau mereka bisa menghindari atau pun apasih yang semestinya sebagai remaja yang mereka lakukan apa yang harus dihindari dan apa yang baik dan apa yang benar untuk mereka." R2 mengungkapkan "mungkin setelah mereka baca, akhirnya mereka tau jadi informasi yang awalnya mereka tidak tahu hal-hal yang beresiko seperti apa saja saja, kemudian secara tidak langsung lambat laun terkait juga dengan obrolan mereka sesama temannya mungkin membahas karena ini di media social kan ada teman-teman bersama seperti itu akhirnya sering koment disana". Selanjutnya R2 menambahkan informasi bahwa dampak media yang digunakan dalam edukasi belum terbukti berimbas pada perilaku remaja, hal ini terungkap dalam pernyataan R2 "Mungkin pada satu titik nanti akan berimbas juga pada perilakunya nanti. Jadi mereka sudah tahu apa yang benar, apa yang baik dilakukan apa yang tidak". Pernyataan R3 dan R6 juga memperkuat bukti tentang adanya dampak kognitif berupa terbentuknya pengetahuan atau tahu pada remaja tentang perilaku seksual berisiko R3 mengungkapkan "kalau dampak positif, hanya tahu saja ini berbahaya, itu tidak. Cuma gitu aja". R6 mengungkapkan dalam pernyataan "bagi remaja dan masyarakat dapat mempelajari dan bisa memberi tahu atau menasehati atau remaja tersebut agar menjadi lebih baik dari sebelumnya”. Sejalan dengan pernyataan responden yang lain, R7 menyebutkan "para remaja dapat mengetahui bagaimana dampak negatif dari seks bebas, mereka jadi bisa melindungi diri dan mempelajari hal-hal tentang pembelajaran seksual".

Pada wawancara terungkap beberapa fakta yang menyatakan bahwa dampak media edukasi tersebut justru bersifat negatif, seperti yang diungkapkan oleh R3 "Jadi mungkin seperti itu dampaknya sekarang, itu dampak negatif ya....................jadi gini oo kalau kita misalnya mendengarkan kata-kata di silde 
itu di power point itu ya bagus ya jadinya tapi kalau kita tidak dengerin, ya lain lagi. Makanya sampai dampak tadi mungkin yang negatif. R3 menyoroti bahwa kemungkinan media yang digunakan tidak mendapat perhatian dari siswa, sehingga justru menimbulkan dampak negatif dalam arti kerugian bahwa yang dilakukan tidak memberikan perubahan apapun terhadap subyek. R3 berasal dari kalangan KPAD Badung memiliki pandangan tentang efektifitas media edukasi terhadap kondisi yang menjadi harapan dari kegiatan tersebut. Memperkuat informasi R3, R5 menyatakan bahwa perilaku negatif masih juga terjadi, dalam pernyataannya R5 menyebutkan "kurang baik karena pergaulan saat ini menekankan pada perilaku yang kurang baik contohnya pada saat pulang sekolah, murid malah bukan pulang ke rumanya tetapi berkeliaran atau nongkrong di salah satu tempat dengan masih menggunakan seragam sekolah". Hal ini menegaskan bahwa media edukasi yang digunakan belum berdampak secara luas terhadap perilaku remaja di kabupaten Badung. R5 masih menjumpai adanya perilaku yang belum sesuai dengan harapan media edukasi.

Pada bagian ini juga dijumpai responden yang tidak mengkonfirmasi apapun tentang dampak media edukasi secara luas terhadap perilaku remaja di kabupaten Badung, yaitu R4.

\section{Media cocok digunakan untuk edukasi tentang perilaku seksual berisiko pada remaja di sekolah menengah pertama (SMP), sesuai dengan kondisi dan situasi di kabupaten Badung}

Berdasarkan hasil wawancara dengan seluruh responden terungkap media yang menurut responden cocok digunakan dipengaruhi oleh faktor latar belakang dan pengalaman responden yang berbeda yaitu KPAD Badung dan siswa SMP. Media power poin terkonfirmasi pada R3, R5 dan R7. R3 menyebutkan "Jadi ilustrasi ya di media itu, slide masih boleh, lembar balik masih boleh, brosur dan kegiatan-kegiatan talkshow kemudian grafity", R5 menyebutkan dengan menggunakan media penyuluhan atau sosialisasi karena kita kan bisa bertanya langsung kepada yang memberika sosialisasi pengaruh apa saja yang terjadi bila kita melakukan perilaku yang tidak baik dan perilaku yang baik. R7 menyebutkan ““'menurut saya media yang paling cocok itu adalah media power point seperti 
penyuluhan karena dengan adanya penyuluhan remaja lebih gampang mengerti dan menyerap pembelajaran-pembelajaran tentang perilaku seksual".

Media liflet/leaflet/brosur) terkkonfirmasi pada dua responden sebagai media yang menurut mereka paling cocok digunakan yaitu R3dan R2. R3 menyebutkan "R3 "Jadi ilustrasi ya di media itu, slide masih boleh, lembar balik masih boleh, brosur dan kegiatan-kegiatan talkshow kemudian grafity”. R2 menyatakan "kalau menurut saya kalau melalui sekolah memang seperti brosur liflet seperti itu". Lembar balik terkonfirmasi pada R4 dan juga R3 sebagaimana petikan wawancara $\mathrm{R} 3$ diatas.

Media sosial terkonfirasi hanya pada satu responden yaitu R6 dalam pernyataannya sebagai berikut "seperti yang saya sampaikan tadi pada pertanyaan yang ketiga sama media yang digunakan itu adalah media social karena dia itu mencakup seluruhnya...........". Demikian juga untuk media video, video terkonfirmasi hanya pada R1, R1 menyatakan "kenapa video itu karena video itu seperti yang saya jelaskan tadi, video itu lebih interaktif dengan siswa.

\section{Simpulan dan Saran}

Simpulan dalam penelitian ini adalah :

1. Media yang diketahui responden untuk meyampaikan materi tentang perilaku seksual berisiko pada remaja SMP di Kabupaten Badung adalah adalah lembar balik, slide power poin, leaflet/brosur, media sosial, tayangan video, tv, buku-buku, dan teman sebaya.

2. Media yang pernah digunakan dalam program edukasi tentang perilaku seksual berisiko pada remaja di sekolah menengah pertama (SMP) di Kabupaten Badung adalah lembar balik, sosial media, liflet (leaflet/brosur), slide/Power Poin dan artikel di majalah.

3. Media apa yang paling sering digunakan dalam program edukasi tentang perilaku seksual berisiko pada remaja di sekolah menengah pertama (SMP) adalah media sosial kemudian disusul oleh leaflet dan slide power poin.

4. Tingkat keberhasilan dari hasil media yang paling sering digunakan dalam program edukasi tentang perilaku seksual berisiko pada remaja di sekolah menengah pertama (SMP) belum dapat dijelaskan. 
5. Dampak media edukasi terhadap perilaku remaja mempengaruhi kognitif siswa (pengetahuan atau tahu) tentang perilaku seksual berisiko, selain itu juga dijumpai dampak negatif yaitu media yang digunakan dalam edukasi belum terbukti berimbas pada perilaku remaja.

6. Media yang cocok digunakan untuk edukasi tentang perilaku seksual berisiko pada remaja di sekolah menengah pertama (SMP), sesuai dengan kondisi dan situasi di kabupaten Badung adalah slide power poin, leaflet/brosur, media sosial dan video.

\section{Saran}

Berdasarkan hasil penelitian, peneliti merekomendasikan beberapa hal berikut :

1. Kepada peneliti selanjutnya, agar mengevaluasi hasil edukasi dengan media yang selama ini dilakukan dengan melihat kedalaman pencapaian indikator kognitif (analisis ranah kognitif), pencapaian sikap serta tindakan.

2. Kepada Satuan Kerja Pemerintah Daerah kabupaten Badung sebagai pemangku kepentingan, diharapkan dapat menyusun road map promosi kesehatan untuk remaja dalam rangka mencegah dan menanggulangi perilaku seksual berisiko pada remaja.

3. Kepada inisiator program kesehatan masyarakat di kabupaten badung, hendaknya mengembangkan media edukasi dan satuan acara penyuluhan dalam rangka mencegah dan menanggulangi perilaku seksual berisiko pada remaja.

\section{Pustaka}

Chandra. E. 2011. Efektivitas Media Pembela Jaran Dalam Pembelajaran Biologi (Meta Analisis terhadap Penelitian Eksperimen dalam Pembelajaran Biologi). Jurnal Holistik Vol 12 Nomor 01, Juni 2011/1433 H.

Effendy, Onong Uchjana. 1989. Kamus Komunikasi. Bandung : PT. Mandar Maju A

Indonesia, 2008. Peraturan Pemerintah Republik Indonesia Nomor 47 Tahun 2008 Tentang Wajib Belajar.

Indonesia, 2016. Peraturan Menteri Pendidikan Dan Kebudayaan Republik Indonesia Nomor 19 tahun 2016 tentang Program Indonesia Pintar. 
Kemenkes RI. 2011. Promosi Kesehatan Di Daerah Bermasalah Kesehatan (Panduan bagi Petugas Kesehatan di Puskesmas). Kementerian Kesehatan Republik Indonesia.

Kholid A. 2015. Promosi Kesehatan : Dengan Pendekatan Teori Perilaku, Media, dan Aplikasinya untuk Mahasiswa dan Praktisi Kesehatan. PT. Rajagrafindo Persada.

Maulana, Herry. (2007). Promosi Kesehatan. Jakarta : EGC

Notoatmodjo. 2008. Promosi Kesehatan di Sekolah. Pusat Promosi Kesehatan Depatemen Kesehatan Republik Indonesia.

Partiyah. 2010. Efektifitas Penggunaan Media Pembelajaran Pendidikan Agama Islam Di Sdn Krapyak 2 Ngemplak Kabupaten Sleman. Jurusan Pendidikan Agama Islam Fakultas Agama Islam Universitas Islam Indonesia.

Sarwono. 2001. Psikologi Remaja. PT. Rajagrafindo Persada

Sukamdani. 2007. Studi Kualitatif Pengetahuan dan Peran Tokoh Masyarakat Dalam Pengendalian Deman Berdarah Degue Di Kota Salatiga Media Litbang Kesehtan Volume XVII Nomor 4 Tahun 2007.

Wati E.R. 2016. Ragam Media Pembelajaran Visual-Audiovisual-KomputerPoerpoint-Internet-Interactive Video. ISBN :978-602-1296-27-1. Kata Pena. 